\title{
DUALISME KELEMBAGAAN ANTARA PEMERINTAH KOTA DAN BADAN PENGUSAHAAN BATAM SERTA DAMPAKNYA TERHADAP KINERJA PEREKONOMIAN DI KOTA BATAM
}

\author{
Muhammad Zaenuddin ${ }^{1}$ ) Wahyudi Kumorotomo ${ }^{2}$ ), Samsubar Saleh ${ }^{3}$ ), Agus H. Hadna ${ }^{4}$ ) \\ 1) Jurusan Managemen Bisnis, Politeknik Negeri Batam, email: zaen @ polibatam.ac.id \\ 2) Program Studi : Studi Kebijakan, Sekolah Pasca Sarjana, Universitas Gadjah Mada
}

\begin{abstract}
The development of special areas of Batam began in the 1970s. With the support of special regulations made by the central government, Batam City becomes a competitive place for investment in Indonesia. Moreover Batam has geographical advantage because of its strategic location and adjacent to Malaysia and Singapore. However, problems arise when the central government begins to impose regional autonomy. The birth of Batam City caused an overlapping of authority between the Local Government of Batam and the Batam Authority which caused the management of Batam Island to be not harmonious. This study aims to identify the problem of institutional dualism that occurred between the Local Government of Batam and the Batam Authority and its impact on economic performance in Batam City. This research is explanatory, the data used are primary and secondary data. The results show the fact that the main problems in governance in Batam City is the occurrence of dualism authority between the Local Government of Batam and the Batam Authority. This is shown by the fact that the overlapping of authority between Local Government of Batam and the Batam Authority occurs in several sectors, especially in land management, overlapping licensing in Batam, airport and port management. This condition led to a decline in economic performance in Batam and the decline of Batam's economic competitiveness.
\end{abstract}

Keywords : special areas of Batam, investment, overlapping of authority, economic performance

Perkembangan daerah khusus Batam dimulai pada tahun 1970an. Dengan dukungan peraturan khusus yang dibuat oleh pemerintah pusat, Kota Batam menjadi tempat investasi yang kompetitif di Indonesia. Apalagi Batam memiliki keunggulan geografis karena letaknya yang strategis dan berdekatan dengan Malaysia dan Singapura. Namun, masalah muncul saat pemerintah pusat mulai memberlakukan otonomi daerah. Kelahiran Kota Batam menyebabkan tumpang tindih kewenangan antara Pemerintah Daerah Batam dan Otorita Batam yang menyebabkan pengelolaan Pulau Batam tidak harmonis. Penelitian ini bertujuan untuk mengidentifikasi masalah dualisme kelembagaan yang terjadi antara Pemerintah Daerah Batam dan Otoritas Batam dan dampaknya terhadap kinerja ekonomi di Kota Batam. Penelitian ini bersifat explanatory, data yang digunakan adalah data primer dan data sekunder. Hasil penelitian menunjukkan bahwa permasalahan utama tata kelola di Kota Batam adalah terjadinya dualisme kewenangan antara Pemerintah Daerah Batam dan Otorita Batam. Hal ini ditunjukkan oleh fakta bahwa tumpang tindih kewenangan antara Pemerintah Daerah Batam dan Otorita Batam terjadi di beberapa sektor, terutama pengelolaan lahan, perizinan yang tumpang tindih di Batam, bandara dan manajemen pelabuhan. Kondisi ini menyebabkan turunnya kinerja ekonomi di Batam dan turunnya daya saing ekonomi Batam.

Kata kunci: daerah khusus Batam, investasi, tumpang tindih kewenangan, kinerja ekonomi 


\section{PENDAHULUAN}

Sejak tahun 1970-an pada periode awal pembangunan Pulau Batam, daerah ini telah diidentikkan dengan kawasan khusus karena berbagai kebijakan khusus yang telah diberikan dan berbeda dengan daerah lainnya di Indonesia. Salah satu alasan mengapa Batam dikembangkan dengan kebijakan khusus adalah karena Batam merupakan salah satu kota dengan letak yang sangat strategis. Selain berada di jalur pelayaran internasional, Batam juga memiliki jarak yang dekat dan berbatasan langsung dengan Singapura dan Malaysia. Kini, Batam telah menjadi salah satu kota dengan pertumbuhan terpesat di Indonesia. Ketika dibangun tahun 1970-an oleh Otorita Batam, kota ini hanya dihuni sekitar 6.000 penduduk dan dalam tempo 40 tahun (pada tahun 2010) penduduk Batam bertumbuh hingga 158 kali lipat, dan kini tumbuh hingga 300 kali lipat (BP Batam, 2017).

Berdasarkan Buku Pembangunan Batam (BP Batam, 2011) sejarah pengembangan Batam dimulai tahun 1968 ketika pertama kali Pertamina menjadikan Pulau Batam sebagai pangkalan logistik dan operasional kegiatan eksplorasi minyak lepas pantai. Periode berikutnya pembangunan Batam secara nyata dimulai sejak tahun 1970-an sebagai tahap persiapan dipimpin oleh Ibnu Sutowo. Akibat terjadi krisis Pertamina, pada tahun 1976 kepemimpinan Batam dialihkan kepada Menteri Penertiban Aparatur Pembangunan yang pada waktu itu dijabat oleh JB. Sumarlin dan dikenal sebagai periode konsolidasi. Pembangunan Batam saat itu sama sekali tidak mengalami perkembangan, karena minyak bumi yang pada tahun 1970 merupakan primadona pasar dunia dan andalan Indonesia, pada tahun 1976 tersebut tidak lagi bisa diandalkan.

Pada periode berikutnya yakni tahun 1978, di bawah kepemimpinan BJ Habibie yang berlangsung 1978-1998 dikenal sebagai periode pembangunan prasarana dan penanaman modal sehingga pada periode ini sarana dan infrastruktur Batam berkembang pesat. Periode berikutnya 1998- 2005, kepemimpinan Batam dipegang oleh Ismeth Abdullah. Periode ini merupakan pengembangan pembangunan prasarana dan penanaman modal lanjutan dengan perhatian lebih besar pada kesejahteraan rakyat dan perbaikan iklim investasi. Terhitung
2005-2016, Pulau Batam di bawah kepemimpinan Mustofa Widjaya mengarahkan pada peningkatan sarana \& prasarana, penanaman modal serta kualitas lingkungan hidup (BP Batam, 2017).

Dalam perkembangannya, di samping dianggap memiliki keunggulan geografis yang berbatasan langsung dengan Singapura dan Malaysia, Batam telah berkembang dan memiliki berbagai keunggulan secara ekonomi, antara lain sebagai salah satu daerah di Indonesia yang tidak pernah mengalami krisis ekonomi, fakta ini terlihat pada tahun 2000-an, ketika arus PMA yang masuk ke Indonesia menurun sejak krisis, Batam tetap merupakan daerah tujuan investasi yang menarik dibanding daerah manapun di Indonesia (Kuncoro,2005). Bahkan pada 2005, Kota Batam meraih Investment Award 2005 dari Komite pemantauan Pelaksanaan Otonomi Daerah (KPOOD) karena dinilai sebagai daerah yang paling diminati investor dan menduduki peringkat tertinggi dari sisi daya saing investasi dari 440 dati II di Indonesia selama 2005 (Depdagri,2005). Batam juga merupakan penyumbang ekspor nonmigas kedua terbesar setelah Bali (Kuncoro,2005).

Memang konsep pengembangan kawasan khusus di Batam selama ini dinilai sangat baik dan mendukung perkembangan investasi di Batam. Namun, problematika muncul ketika pemerintah pusat mulai memberlakukan undang-undang tentang Otonomi Daerah termasuk juga ketika diberlakukan di Batam. Hal ini dikarenakan dalam perkembangannya, pemberlakuan undang-undang Otonomi Daerah ternyata memunculkan dualisme kewenangan antara Otorita Batam dan Pemko Batam ketika mulai diberlakukannya Undang- Undang Nomor 22 Tahun 1999 tentang Pemerintah Daerah. Sebagai pelaksanaan otonomi daerah tersebut, Pulau Batam pun ditetapkan menjadi Kota Batam sesuai dengan Undang-Undang Nomor 53 Tahun 1999 tentang Pembentukan Kabupaten Pelalawan, Kabupaten Rokan Hulu, Kabupaten Rokan Hilir, Kabupaten Siak, Kabupaten Karimun, Kabupaten Natuna, Kabupaten Kuantan Singingi, dan Kota Batam.

Menurut Sapta Murti (2014) lahirnya Kota Batam menimbulkan tumpang tindih kewenangan antara Pemko Batam dengan Badan Pengusahaan atau Otorita Batam. Eksistensi 
Muhammad, Wahyudi, Samsubar, \& Agus, Dualisme Kelembagaan antara Pemerintah...

kedua lembaga yang didukung oleh struktur dan substansi hukum yang berbeda menyebabkan kebijakan pengelolaan Pulau Batam tidak harmonis. Keberadaan Badan Pengusahaan yang didahului oleh Otorita Batam berdasarkan Keputusan Presiden Nomor 41 Tahun 1973 dan memiliki kewenangan untuk melakukan pengelolaan Pulau Batam dan semakin diperkuat dengan lahirnya Undang-Undang Nomor 36 Tahun 2000 sebagaimana telah diubah dengan Keputusan Presiden Nomor 44 Tahun 2007, serta Peraturan Pemerintah Nomor 46 Tahun 2007 sebagaimana telah diubah dengan Peraturan Pemerintah Nomorr 5 Tahun 2011 secara vis a vis dengan Undang-Undang Nomor 22 Tahun 1999 sebagaimana telah diubah dengan Undang- Undang Nomor 32 Tahun 2004 serta Undang- Undang Nomor 53 Tahun 1999.

Menurut Bayu Putra (2014) hadirnya daerah otonom yaitu Kota Batam menimbulkan tumpang tindih kewenangan antara Pemko Batam dengan Badan Pengusahaan. Eksistensi kedua kelembagaan tersebut yang didukung oleh substansi hukum dan struktur yang berbeda membuat pelaksanaan kebijakan pengelolaan Batam tidak harmonis. Tumpang tindih tersebut terdapat dalam beberapa urusan di Batam, di antaranya adalah masalah lahan. Bidang pertanahan di Pulau Batam merupakan bidang yang kewenangan pengelolaannya dimiliki oleh 2 (dua) institusi pemerintahan daerah, yaitu antara Pemko Batam dan Badan Pengelola Batam. Pemko mendasarkan kewenangannya pada ketentuan pasal 9 ayat (4) jo Pasal 12 ayat (2) huruf d Undang-undang Nomor 23 Tahun 2014 tentang Pemerintahan Daerah yang pada hakikatnya telah menyatakan bahwa bidang 'pertanahan' merupakan Urusan Pemerintahan kongkuren yang diserahkan ke daerah yang menjadi dasar pelaksanaan Otonomi Daerah. Sedangkan Badan Pengelola Batam mendesarkan kewenangannya pada Keputusan Presisden Nomor 41 Tahun 1973 tentang Daerah Industri Pulau Batam yang terkait hak penggunaan tanah serta Undang-undang 36 Tahun 2000 yang terkait kewenangan menerbitkan izin usaha yang didirikan di atas tanah. Dengan demikian Badan Pengelola Batam 'juga' memiliki kewenangan 'yang sama' dengan Pemko Batam di bidang pertanahan. Benturan kewenangan antara Badan Pengusahaan dengan Pemerintah Kota Batam juga terjadi pada bidang lainnya antara lain pengelolaan kepelabuhan dan kebandarudaraan di Batam, masalah perizinan dan urusan kepariwisataan.

Secara substansi hukum antara Pemkot Batam dan Badan Pengusahaan terjadi benturan, baik pengaturan Pulau Batam dalam kerangka daerah industri dan kemudian berkembang menjadi kawasan perdagangan bebas dan pelabuhan bebas, maupun dalam kerangka pengaturan otonomi daerah. Kewenangan tersebut berimplikasi pada tidak harmonisnya penyelenggaraan Pulau Batam karena terjadinya dualisme kelembagaan yang mengelolanya sehingga hal tersebut akan berdampak pada masyarakat secara umum.

Menurut penelitian Putra (2014) menunjukkan bahwa munculnya dualisme kewenangan di Kota Batam selain karena adanya implementasi desentralisasi juga dipengaruhi oleh faktor lain yaitu Pertama, adanya benturan regulasi antara Pemerintah Kota Batam dan Badan Pengusahaan Batam. Kedua, tidak adanya peraturan tentang hubungan kerja antara Pemerintah Kota Batam dan Badan Pengusahaan Batam. Ketiga, adanya tarik menarik kepentingan dalam pengelolaan keuangan atas sumber daya dan perizinan yang ada di Kota Batam. Adanya dualisme kewenangan dalam pelayanan administrasi penanaman modal di Kota Batam memiliki dampak negative bagi investor, dampak tersebut antara lain: Pertama, Tidak adanya kepastian hukum bagi investor selaku penanam modal. Kedua, Prosedur dan waktu perizinan yang lebih panjang dan lama Ketiga, Double cost atau biaya tambahan bagi investor.

Penelitian ini bertujuan untuk mengidentifikasi permasalahan dualisme kelembagaan yang terjadi antara Pemerintah Kota dan Badan Pengusahaan Batam dan dampaknya terhadap kinerja perekonomian di Kota Batam.

\section{KAJIAN TEORI}

\section{Kewenangan dan Kedaulatan}

Esensi dari otonomi daerah sesungguhnya adalah peningkatan kualitas pelayanan kepada masyarakat. Guna mewujudkan pelayanan yang berkualitas lebih baik maka perlu pemberdayaan kepada daerah dengan memberi kewenangan kepada daerah untuk mengambil langkah langkah yang cepat dan tepat sesuai dengan kebutuhan daerah. Sehingga masyarakat semakin merasakan adanya signifikansi dari perbaikan/peningkatan kualitas pelayanan. 
Mencermati literatur asing bahwa secara konsepsional Pemerintah Indonesia telah mengambil bentuk sendiri dalam format pengertian desentralisasi yang mana desentralisasi di Indonesia tampak disamakan dengan devolusi, yang pada literatur tentang desentralisasi (Cohen dan Peterson 1999; Hoessein, 2001). Cohen dan Peterson menyebutkan bahwa sebagian besar dari literatur tentang desentralisasi difokuskan pada hanya satu dari empat bentuk desentralisasi (political, spatial, market and administrative) yaitu pada administrative desentralization.

Tiga tipe dari desentralisasi administrasi adalah deconsentration, devolution, dan delegation (1999: 24) sementara itu Hoessein menemukan dari berbagai sumber bahwa konsep inilah yang menghiasai berbagai Laporan Bank Dunia dan organisasi internasional (2001).

Defenisi dari administrative desentralization menurut Rondinelli and Nellis, adalah:

"...the transfer of responsibility for planning, management, and the raising and allocation of resources from the central government and its agencies to field unit of government and its agencies, subordinate, semi autonomous publics authorities or corporation, area-wide regional or functional authorities, or non governmental private or voluntary organization" (Cohen and Peterson, 1999;24).

Pengertian di atas tampak menunjukkan secara jelas bahwa administrative decentralization hanyalah suatu penyerahan sejumlah (beberapa) dari pemerintah pusat kepada organ - organ pemerintah dibawahnya atau level pemerintah di bawahnya. Pengertian ini secara jelas menunjukkan administrative deventralization adalah suatu konsepsi yang berada dan dijalankan dalam bingkai negara sehingga tidak mengherankan bahwa untuk kasus Indonesia terjadai permasalahan yang serius dalam implementasi otonomi daerah, khususnya munculnya perkembangan dalam pola pemikiran seakan otonomi itu adalah suatu kedaulatan (sovereignty).

Pertimbangan konsepsional seperti ini selain munculnya fenomena perilaku beberapa daerah yang kurang responsif terhadap penegakan negara kesatuan, yang tampak mendasari rencana penggantian kata pemberian "kewenangan" dalam UU No. 22 tahun 1999 menjadi pemberian urusan dalam rancangan revisi UU 22/1999 tersebut.

Undang - Undang Otonomi Daerah tampak menjadi dasar untuk berbeda pandangan antara daerah. Anehnya otonomi daerah tampak menjadi alat bagi pemerintah daerah untuk meweujudkan kedaulatannya (sovereignty) dibandingkan mengemban misi utama dari otonomi itu sendiri yaitu bagaimana lebih memberdayakan rakyat.

\section{Konsepsi Kewenangan Daerah}

Secara empirik banyak terjadi ketegangan dan friksi antar tingkatan pemerintahan berkaitan dengan konsepsi kewenangan tersebut. Ada tiga jenis friksi, yaitu friksi antara pusat dan daerah; friksi antara daerah provinsi dan kabupaten/kota; dan friksi antar kabupaten/kota sendiri.

Made Suwandi, dalam tulisan Pokok Pokok Pikiran Konsepsi Dasar Otonomi Daerah di Indonesia (2002) memetakan friksi antara pemerintah pusat dan daerah, diantaranya: 1) masalah kewenangan pertanahan antara pemerintah pusat dan pemerintah kabupaten/kota yang ditandai dengan adanya Dinas Pertanahan milik daerah dan Kantor Pertanahan yang masih menginduk ke pusat; 2) masalah kewenangan pelabuhan laut, udara, otorita (kasus Batam), kehutanan, perkebunan (kasus PTPN), dan kewenangan pemberdayaan sumber daya nasional yang ada di daerah bersangkutan; dan 3) masalah kewenangan Tenaga Kerja Asing.

Friksi pada dasarnya berpangkal dari siapa yang mempunyai kewenangan secara hukum atas hal yang disengketakan tersebut. Motif utama yang mendorong adalah bukanlah persoalan untuk memberikan pelayanan masyarakat pada hal yang disengketakan tersebut, namun lebih pada bagaimana menguasai sumber - sumber pendapatan yang dihasilkan dari kewenangan yang disengketakan tersebut.

Daerah menganggap dengan adanya otonomi luas maka kebutuhan uang mereka menjadi tidak terbatas. Sedangkan PAD dan DAU terbatas sehingga hal tersebut menarik mereka untuk menambah sumber - sumber penerimaan dari penguasaan objek - objek yang dapat menghasilkan tambahan penerimaan daeah. 
Muhammad, Wahyudi, Samsubar, \& Agus, Dualisme Kelembagaan antara Pemerintah...

Sedangkan pusat berpendapat objek tersebut adalah menyangkut kepentingan nasional sehingga menganggap perlu penguasaan pusat atas objek tersebut. Daerah berpegang pada pasal 7 (1), pasal 11, dan pasal 19 UU 22 tahun 1999, sedangkan pusat juga berpegang pada pasal 7 (2) sebagai kewenangan atas sumber - sumber perekonomian nasional.

Dari analisis di atas terdapat kontradiksi dalam tataran normatif terutama kewenangan dalam perekonomian negara. Pasal 7 (2) menyatakan kewenangan dalam perekonomian negara menjadi domain kewenangan bidang lain yang menjadi kewenangan pusat. Sedangkan pasal 119 (1) menyatakan bahwa kewenangan kabupaten/kota berlaku juga di kawasan otorita, kawasan pelabuhan, kawasan bandar udara, kawasan perumahan, kawasan industri, kawasan perkebunan, kawasan pertambangan, kawasan kehutanan, kawasan pariwisata, kawasan jalan bebas hambatan, dan kawasan lain yang sejenis. Departemen sektoral berpegang pada pasal 7(2) ditambah dengan UU yang mengatur sektor itu sendiri, sedangkan daerah berpegang pada pasal 119 (1) UU 22/1999.

\section{METODOLOGI PENELITIAN}

Penelitian ini bersifat explanatory yakni mengumpulkan data kuantitatif terlebih dahulu dan dilanjutkan dengan data kualitatif. Hasil analisis dan interpretasi dari data kuantitatif tersebut akan melengkapi data kualitatif, sehingga diperoleh analisis deskriptif yang akurat dan komprehensif. Data yang digunakan adalah data sekunder yakni berupa laporan ekonomi tahunan dari Pemerintah Kota Batam tahun 2001-2011, dan data primer berupa wawancara dengan pihak-pihak yang terkait antara lain Pemerintah Kota Batam, Badan Pengusahaan Kawasan FTZ Batam, tokoh masyarakat, DPRD Kota Batam, dan pelaku usaha/industri di Batam.

\section{HASIL DAN PEMBAHASAN \\ Tumpang Tindih Kewenangan antara Pemerintah Kota dan Badan Pengusahaan Batam}

Hadirnya daerah otonom yaitu Kota Batam menimbulkan tumpang tindih kewenangan antara Pemko Batam dengan Badan Pengusahaan. Eksistensi kedua kelembagaan tersebut yang didukung oleh substansi hukum dan struktur yang berbeda membuat pelaksanaan kebijakan pengelolaan Batam tidak harmonis. Menurut hasil penelitian lapangan dan juga berdasarkan kajian dari Kemenkumham tentang Batam (2016), terdapat beberapa hubungan tumpang tindih yang tergambar dalam beberapa urusan berikut.

\section{a. Hak Pengelolaan Lahan di Batam}

Diantara sekian banyak kewenangan yang sudah dilimpahkan kepada Pemkot Batam sesuai UU 32/2004, maka kewenangan dalam pengelolaan lahan adalah hal yang paling krusial dan sangat disorot oleh para pemangku kepentingan di kota ini. Kondisi ini semakin diperparah oleh perbedaan konsepsi Otonomi Daerah oleh Pemkot Batam yang menganut faham penguasaan wilayah melalui kewenangan pengelolaan lahan.

Pemko mendasarkan kewenangannya pada ketentuan pasal 9 ayat (4) jo Pasal 12 ayat (2) huruf d Undang-undang Nomor 23 Tahun 2014 tentang Pemerintahan Daerah yang pada hakikatnya telah menyatakan bahwa bidang 'pertanahan' merupakan Urusan Pemerintahan kongkuren yang diserahkan ke daerah yang menjadi dasar pelaksanaan Otonomi Daerah. Pertanahan sebagai urusan pemerintahan konkruen dimaksud ditegaskan lagi sebagai Urusan Pemerintahan Wajib. Dengan demikian, berdasarkan norma hokum dalam Undangundang Nomor 23 tahun 2014 ini maka Pemko Batam memiliki kewenangan di bidang pertanahan.

Sedangkan Badan Pengelola Batam mendesarkan kewenangannya pada ketentuan : (i) pasal 6 ayat (2) huruf b Keputusan Presisden Nomor 41 Tahun 1973 tentang Daerah Industri Pulau Batam yang terkait hak penggunaan tanah; (ii) Keputusan Menteri Dalam Negeri Nomor 43 Tahun 1977 tentang Pengelolaan dan Penggunaan Tanah di Daerah Industri Pulau Batam yang memberikan kewenangan menerbitkan izin usaha di atas lahan Pulau Batam; (iii) Pasal 10 Undang-undang 36 Tahun 2000 yang terkait kewenangan menerbitkan izin usaha yang didirikan di atas tanah. Dengan demikian Badan Pengelola Batam 'juga' memiliki kewenangan 'yang sama' dengan Pemko Batam di bidang pertanahan.

\section{b. Tumpang Tindih dalam Hal} Perizinan

Berdasarkan Pasal 11 ayat (2) UndangUndang Nomor 36 Tahun 2000 tentang Penetapan Peraturan Pemerintah Pengganti Undang-undang Nomor 1 Tahun 2000 tentang 
Kawasan Perdagangan Bebas dan Pelabuhan Bebas menjadi Undang-Undang sebagimana telah diubah menjadi Undang-Undang Nomor 44 Tahun 2007, pemasukan dan pengeluaran barang ke dan dari Kawasan Perdagangan Bebas dan Pelabuhan Bebas hanya dapat dilakukan oleh pengusaha yang telah mendapatkan izin dari Badan Pengusahaan (BP Batam). Hal ini memberikan kewenangan kepada BP Batam memberikan izin usaha kepada orang perseorangan atau badan hokum untuk melakukan kegiatan pemasukan barang (impor) dan pengeluaran barang (ekspor).

Sementara ketentuan Pasal 24 ayat (1) dan ayat (2) Undang-Undang Nomor 7 Tahun 2014 tentang Perdagangan menyatakan bahwa Pelaku Usaha yang melakukan kegiatan usaha Perdagangan wajib memiliki perizinan di bidang perdagangan (termasuk ekspor dan impor) yang diberikan oleh Menteri Perdagangan. Menteri dapat melimpahkan atau mendelegasikan pemberian izin kepada Pemerintah Daerah atau instansi teknis tertentu. Hal ini sangat jelas bahwa kewenangan pemberian izin usaha dalah milik Menteri Perdagangan. Dari ketentuan ini maka terdapat dualism pengaturan terkait otoritas yang mempunyai kewenangan untuk mengeluarkan izin usaha pemasukan (impor) dan pengeluaran (impor) di Kawasan Perdagangan Bebas dan Pelabuhan Bebas Batam. Atas kondisi ini para pelaku usaha dirugikan akibat adanya dualisme perizinan dan kewenangan antara BP Batam dan Pemko Batam. Akibat kondisi ini maka Batam dinilai Investor kurang kelas yang berakibat biaya produksi tinggi.

Adanya dualisme kewenangan antara

Pemerintah Kota Batam dan Badan Pengusahaan Batam juga terjadi benturan regulasi dalam hal pelayanan administrasi penanaman modal yang terjadi di Kota Batam. Dari kedua kewenangan yang dimiliki baik dari Pemerintah Kota Batam dan Badan Pengusahaan Batam memperlihatkan bahwa memang terjadi dualisme kewenangan dalam pelayanan administrasi penanaman modal di Kota Batam, hal ini karena dalam pembagian kewenangan yang berkaitan dengan penanaman modal di Kota Batam ada kewenangan berupa perizinan yang hampir sama namun dilakukan oleh dua badan yang berbeda ini. Adapun jenis- jenis perizinan yang hampir sama namun dilakukan oleh kedua badan tersebut antara lain:

Tabel 1. Perizinan yang memiliki kesamaan namun dilakukan oleh dua badan

\begin{tabular}{|c|c|c|c|}
\hline No & Bidang & $\begin{array}{l}\text { Perizinan } \\
\text { yang } \\
\text { dimiliki } \\
\text { oleh } \\
\text { Pemerintah } \\
\text { Kota Batam }\end{array}$ & $\begin{array}{l}\text { Perizinan } \\
\text { yang dimiliki } \\
\text { oleh Badan } \\
\text { Pengusahaan } \\
\text { Batam }\end{array}$ \\
\hline \multirow[t]{2}{*}{1} & \multirow[t]{2}{*}{$\begin{array}{l}\text { Penggunaan } \\
\text { lahan dan } \\
\text { bangunan }\end{array}$} & $\begin{array}{l}\text { Izin } \\
\text { Mendirikan } \\
\text { Bangunan }\end{array}$ & $\begin{array}{l}\text { Fatwa } \\
\text { Planologi dan } \\
\text { pematangan } \\
\text { lahan }\end{array}$ \\
\hline & & \begin{tabular}{lr}
\multicolumn{2}{l}{ Dilakukan } \\
Oleh Dinas \\
Tata Kota \\
Batam
\end{tabular} & $\begin{array}{l}\text { Dilakukan } \\
\text { oleh } \\
\text { Direktorat } \\
\text { Pengolahan } \\
\text { Lahan Badan } \\
\text { Pengusahaan } \\
\text { Batam }\end{array}$ \\
\hline \multirow[t]{2}{*}{2} & \multirow[t]{2}{*}{ Reklame } & $\begin{array}{l}\text { Perizinan } \\
\text { pendirian } \\
\text { dan } \\
\text { Pemasangan } \\
\text { Reklame }\end{array}$ & $\begin{array}{l}\text { Izin Titik } \\
\text { Konstruksi } \\
\text { Reklame }\end{array}$ \\
\hline & & $\begin{array}{l}\text { Dilakukan } \\
\text { oleh Dinas } \\
\text { Pendapatan } \\
\text { Daerah }\end{array}$ & $\begin{array}{l}\text { Dilakukan } \\
\text { oleh } \\
\text { Direktorat } \\
\text { investasi } \quad \text { \& } \\
\text { marketing } \\
\text { BP } \\
\text { Batam }\end{array}$ \\
\hline \multirow[t]{2}{*}{3} & \multirow[t]{2}{*}{ Perdagangan } & Izin Usaha & $\begin{array}{l}\text { Registrasi } \\
\text { Perusahaan } \\
\text { dan Pemberian } \\
\text { Izin Usaha }\end{array}$ \\
\hline & & $\begin{array}{l}\text { Badan } \\
\text { Penanaman } \\
\text { Modal Kota } \\
\text { Batam }\end{array}$ & $\begin{array}{l}\text { Direktorat } \\
\text { Investasi } \quad \& \\
\text { marketing } \\
\text { Batam BP }\end{array}$ \\
\hline \multirow[t]{2}{*}{4} & \multirow[t]{2}{*}{ Perdagangan } & $\begin{array}{l}\text { Surat Izin } \\
\text { Usaha } \\
\text { Perdagangan }\end{array}$ & $\begin{array}{l}\text { Surat Izin } \\
\text { Usaha } \\
\text { Perdagangan }\end{array}$ \\
\hline & & $\begin{array}{l}\text { Dinas } \\
\text { Perindustria } \\
\mathrm{n}, \\
\text { Perdagangan } \\
\text {, Energi dan } \\
\text { Sumber } \\
\text { Daya Kota } \\
\text { Batam }\end{array}$ & $\begin{array}{l}\text { Direktorat } \\
\text { Investasi } \quad \& \\
\text { marketing } \\
\text { Batam BP }\end{array}$ \\
\hline \multirow[t]{2}{*}{5} & \multirow[t]{2}{*}{ Perdagangan } & $\begin{array}{l}\text { Tanda } \\
\text { Daftar } \\
\text { Perusahaan }\end{array}$ & $\begin{array}{l}\text { Tanda Daftar } \\
\text { Perusahaan }\end{array}$ \\
\hline & & Dinas & Direktorat \\
\hline
\end{tabular}


Muhammad, Wahyudi, Samsubar, \& Agus, Dualisme Kelembagaan antara Pemerintah...

\begin{tabular}{|c|c|c|c|}
\hline & & $\begin{array}{l}\text { Perindustria } \\
\mathrm{n} \text {, } \\
\text { Perdagangan } \\
\text {, Energi dan } \\
\text { Sumber } \\
\text { Daya Kota } \\
\text { Batam }\end{array}$ & $\begin{array}{ll}\text { Investasi } \quad \& \\
\text { marketing }\end{array}$ \\
\hline \multirow[t]{2}{*}{6} & \multirow[t]{2}{*}{ Perdagangan } & $\begin{array}{l}\text { Tanda } \\
\text { Daftar } \\
\text { Gudang }\end{array}$ & $\begin{array}{l}\text { Tanda Daftar } \\
\text { Gudang }\end{array}$ \\
\hline & & $\begin{array}{l}\text { Dinas } \\
\text { Perindustria } \\
\mathrm{n}, \\
\text { Perdagangan } \\
\text {, Energi dan } \\
\text { Sumber } \\
\text { Daya Kota } \\
\text { Batam }\end{array}$ & $\begin{array}{l}\text { Direktorat } \\
\text { Investasi } \quad \& \\
\text { marketing } \\
\text { Batam BP }\end{array}$ \\
\hline
\end{tabular}

Sumber: Diolah penulis

Dari tabel diatas terlihat bahwa ada perizinan yang dilakukan oleh Pemerintah Kota Batam dan ada perizinan yang dilakukan oleh Badan Pengusahaan Batam dalam pelayanan administrasi penanaman modal di Kota Batam. Dari perizinan tersebut terdapat perizinan yang hampir memiliki kesamaan antara keduanya. Padahal semestinya izin tersebut cukup dilakukan oleh salah satu pihak saja. Hal ini semakin memperjelas adanya dualisme kewenangan yang terjadi di Kota Batam.

\section{Pengelolaan Pelabuhanan}

c. Tumpang Tindih Kewenangan dalam

Benturan kewenangan di bidang kepelabuhan antara Badan Pengusahaan dengan Pemerintah Kota Batam didasarkan pada konflik norma antara Undang-undang Nomor 36 Tahun 2000 tentang Penetapan Peraturan Pemerintah Pengganti Undang-undang Nomor 1 Tahun 2000 tentang Kawasan Perdagangan Bebas dan Pelabuhan Bebas Batam dengan Undang-undang Nomor 17 tahun 2008 tentang Pelayaran dan Undang-undang Nomor 32 Tahun 2004 tentang Pemerintah Daerah sebagaimana telah dicabut dengan Undang-undang Nomor 23 tahun 2014 tentang Pemerintah Daerah.

Konflik norma tersebut yaitu Pasal 9 ayat (1) Undang-undang Nomor 36 tahun 2000 yang berbunyi : Kawasan Perdagangan Bebas dan Pelabuhan Bebas mempunyai fungsi sebagai tempat untuk mengembangkan usaha-usaha di bidang perdagangan, jasa, industry, pertambangan dan energy, transportasi, maritime, dan perikanan, pos, dan telekomunikasi, perbankan, asuransi, pariwisata, dan bidang-bidang lainnya. Selanjutnya Pasal 9 ayat (2)nya menyatakan fungsi sebagaimana dimaksud dalam ayat 91) meliputi : a. kegiatan manufaktur, rancang bangun, perekayasaan, penyortiran, pemeriksaan awal, pemeriksaan akhir, pengepakan, dan pengepakan ulang atas barang dan bahan baku dari dalam dan luar negeri, pelayanan perbaikan atau rekondisi permesinan, dan peningkatan mutu; b. penyediaan dan pengembangan prasarana dan sarana air dan sumber air, prasarana dan sarana perhubungan termasuk pelabuhan laut dan Bandar udara, bangunan dan jaringan listrik, pos dan telekomunikasi, serta prasarana dan sarana lainnya.

Selanjutnya dalam Pasal 8 ayat (2) Undang-undang Nomor 36 tahun 2000 diatur bahwa : "Kepala Badan Pengusahaan mempunyai tugas dan wewenang melaksanakan pengelolaan, pengembangan, dan pembangunan Kawasan Perdagangan Bebas dan Pelabuhan Bebas". Berdasarkan ketentuan tersebut maka Kepala Badan Pengusahaan Batam memiliki kewenangan untuk melaksanakan pengelolaan, pengembangan, dan pembangunan, dalam prasarana dan sarana air dan sumber air, prasarana dan sarana perhubungan termasuk pelabuhan laut sesuai dengan Pasal 9 Undangundang Nomor 36 Tahun 2000.

Kewenangan tersebut dipertegas dalam Pasal 6 Keppres Nomor 41 tahun 1973 yang menetapkan bahwa peruntukan dan penggunaan tanah di daerah industri di Pulau Batam untuk keperluan bangunan-bangunan, usaha-usaha dan fasilitas-fasilitas lainnya, yang bersangkutan dengan pelaksanaan pembangunan Pulau Batam, didasarkan atas suatu rencana tata-guna tanah dalam rangka pengembangan Pulau Batam menjadi Daerah Industri. Hal-hal yang bersangkutan dengan pengurusan tanah di dalam wilayah Daerah Industri Pulau Batam dalam rangka pengembangan Pulau Batam menjadi Daerah Industri diatur lebih lanjut oleh Menteri Dalam Negeri sesuai dengan peraturan perundang-undangan yang berlaku di bidang agrarian, dengan ketentuan sebagai berikut : a. Seluruh arela tanah yang terletak di Pulau Batam diserahkan, dengan hak pengelolaan, kepada Ketua Otorita Pengembangan Daerah Industri Pulau Batam; b. Hak pengelolaan tersebut pada sub a ayat ini memberi wewenang kepada Ketua Otorita Pengembangan Daerah Industri Pulau Batam untuk : 1. Merencanakan peruntukan dan penggunaan tanah tersebut; 2 . Menggunakan tanah tersebut untuk keperluan 
pelaksanaan tugasnya; 3. Menyerahkan bagianbagian dari tanah tersebut kepada pihak ketiga dengan hak-pakai sesuai dengan ketentuanketentuan Pasal 41 sampai Pasal 43 UUPA.

Namun ketentuan yang mengatur Badan pengusahaan Batam tersebut mengalami konflik dengan hadirnya pasal 82 ayat (1) Undangundang Nomor 17 Tahun 2008 yang menyatakan Otoritas pelabuhan sebagaimana dimaksud dalam Pasal 81 ayat (1) huruf a dibentuk oleh dan bertanggung jawab kepada Menteri. Juga bertentangan dengan Pasal 82 ayat (2) Undang-undang Nomor 17 Tahun 2008 yang menyatakan : Unit Penyelenggara pelabuhan sebagaimana dimaksdu dalam Pasal 81 ayat 91) huruf $\mathrm{b}$ dibentuk dan bertanggung jawab kepada : a. Menteri untuk Unit Penyelenggara pelabuhan Pemerintah; dan $b$. gubernur atau bupate/walikota untuk Unit Penyelenggara Pelabuhan Pemerintah Daerah.

Berdasarkan ketentuan Pasal 82 ayat (1) dan ayat (20 Undang-undang Nomor 17 tahun 2008 maka otoritas pelabuhan di Kota Batam. Faktanya, seluruh pelabuhan di Pulau batam yang dibangun oleh badan Pengusahaan sebelum terbentuknya Undang-undang Nomor 17 tahun 2008 dibentuk dan bertanggung jawab kepada kepala Badan Pengusahaan.

Benturan kewenangan di bidang kepelabuhan antara Badan Pengusahaan dengan Pemerintah Kota Batam juga disebabkan beberapa norma lain dalam Undang-undang Nomor 17 tahun 2008 dan Undang-undang pemerintah Daerah yaitu Pasal 97 Undangundang Nomor 17 Tahun 2008 ayat (1) dan ayat (2). Pasal 97 ayat (1) : Pelabuhan laut hanya dapat dioperasikan setelah dibangun dan memenuhi persyaratan operasional serta memperoleh izin. Pasal 97 ayat (2) : izin mengeoperasikan pelabuhan laut diberikan oleh : a. Menteri untuk pelabuhan utama dan pelabuhan pengumpul; dan $b$. gubernur atau bupati/walikota untuk pelabuhan pengumpan.

Pasal 98 Undang-undang Nomor 17 Tahun 2008 tentang Pelayaran juga mengatur, ayat (1) : Pembangunan pelabuhan sungai dan danau wajib memperoleh izin dari bupati/walikota. Ayat (2) : Pembangunan pelabuhan sungai dan danau sebagaimana dimaksud pada ayat (1) dilaksanakan berdasarkan persyaratan teknis kepelabuhanan, kelestarian lingkungan, dengan memperhatikan keterpaduan intra- dan antar moda trasportasi. Ayat (3) Pelabuhan sungai dan danau hanya dapat dioperasikan setelah selesaidibangun dan memenuhi persyaratan opearsional serta memperoleh izin. Ayat 94) : izin mengoperasikan pelabuhan sungai dan danau diberikan oleh bupati/walikota.

Di lampiran Undang-undang Nomor 23 Tahun 2014 Bagian Urusan Pemerintahan Bidang Perhubungan ditetapkan bahwa Pemerintah Kab/Kota memiliki kewenanangan :

a. Penerbitan izin usaha angkutan laut bagi badan usaha yang berdomisili dalam Daerah kabupaten/kota dan beroperasi pada lintas pelabuhan di Daerah kabupaten/kota.

b. Penerbitan izin usaha angkutan laut pelayaran rakyat bagi orang perorangan atau badan usaha yang berdomisili dan yang beroperasi pada lintas pelabuhan dalam Daerah kabupaten/kota.

c. Penerbitan izin usaha penyelenggaraan angkutan sungai dan Pembangunan dan penerbitan izin pembangunan dan pengopersian pelabuhan sungai dan danau.

d. Penerbitan izin usaha badan usaha pelabuhan di pelabuhan pengumpul local

e. Penerbitan izin pengembangan pelabuhan pelabuhan lokal.

f. Penerbitan/pengoperasian pelabuhan untuk pengumpan izin.

g. Penerbitan izin pekerjaan pengerukan di wilayah perairan pelabuhan pengumpan lokal

h. Penerbitan izin reklamasi di wilayah pelabuhan pengumpan lokal

Berdasarkan fakta hukum tersebut di atas, maka jelas terjadi konflik norma peraturan perundang-undangan di bidang kepelabuhanan yang berakibat benturan kewenangan antara Badan Pengusahaan dan Pemerintah Kota Batam.

\section{d. Tumpang Tindih Pengelolaan}

\section{Bandar Udara}

Lahirnya Undang-undang Nomor 1 tahun 2009 tentang penerbangan bertujuan mewujudkan penerbangan yang tertib, teratur, dan kepastian hokum tanpa mengorbankan kelangsungan hidup penyedia jasa transportasi. Dalam Pasal 226 Undang-undang Nomor 1 
Muhammad, Wahyudi, Samsubar, \& Agus, Dualisme Kelembagaan antara Pemerintah...

Tahun 2009 mengatur mengenai penyelenggaraan kegiatan pemerintahan di Bandar udara yang meliputi pembinaan, kepabeanan, keimigrasian, dan kekarantinaan. Pembinaan dilakukan oleh Otoritas Bandar Udara. Sedangkan kepabeanan, keimigrasian, dan kekarantinaan dilaksanakan sesuai dengan ketentuan PUU. Adapun dalam ketentuan PUU tidak ada yang menyerahkan urusan ketiganya kepada Pemerintah Daerah, apalagi kepada Badan Pengusahaan.

Dalam Pasal 227 Undang-undang Nomor 1 Tahun 2009 mengatur bahwa Otoritas Bandar Udara ditetapkan oleh dan bertanggung jawab kepada Menteri Perhubungan. Otoritas tersebut dalam melaksanakan tugasnya harus berkoordinasi dengan pemerintah daerah setempat, yang dalam hal ini Pemko Batam. Sedangkan Otoritas inilah yang mempunyai kewenangan terbesar dalam penyelenggaraan kegiatan di Bandar udara.

Selain kegiatan pemerintahan, dalam Undang-undang Nomor 1 Tahun 2009 ini juga mengatur mengenai kegiatan pengusahaan Bandar udara yang meliputi pelayanan jasa kebandarudaraan dan pelayanan jasa terkait Bandar udara.Pasal 233 Undang-undang Nomor 1 Tahun 2009 mengatur bahwa Pelayanan jasa kebandarudaraan dapat diselenggarakan p;eh : a. Badan usaha Bandar udara untuk Bandar udara yang diusahakan secara komersial setelah memperoleh izin dari Menteri Perhubungan; $b$. unit penyelenggara Bandar udara untuk Bandar udara yang belum diusahakan secara komersial yang dibentuk oleh dan bertanggung jawab kepada pemerintah dan/atau pemerintah daerah.

Terkait dengan Bandar Udara Hang Nadim, yang diatur dalam Peraturan Pemerintah Nomor 65 Tahun 2014 tentang Penyelenggaraan Kegiatan di Bandar Udara Hang Nadim Batam oleh Badan Pengusahaan Kawasan Perdagangan Bebas dan Pelabuhan Bebas Batam, merupakan satu-satunya Bandar udara yang tanggung jawab dan kewenangan penyelenggaraannya tidak berada di tangan Menteri dan pengusahaannya tidak melalui PT Angkasa Pura (Persero),melainkan oleh BP Batam.

Penyelenggaraan Bandar Udara Hang Nadim belum memenuhi ketentuan Undangundang Nomor 1 Tahun 2009 karena BP Batam membentuk Badan Usaha Bandar Udara, yang dalam Pasal 233 ayat (1) huruf a undang-undang Nomor 1 Tahun2 009 mengatur bahwa pembentukan Badan Usaha Bandar Udara harus memperoleh izin dari Menteri. Selain itu dalam Pasal 2 Peraturan Pemerintah Nomor 65 Tahun 2014 mengatur bahwa Badan Pengusahaan Batam membentuk Badan Usaha Bandar Udara Kawasan Batam untuk melakukan kegiatan pengusahaan di Bandar Udara Hang Nadim. BP Batam inilah yang menjadi Badan Usaha Bandar Udara.

Sedangkan dalam Pasal 1 angka 43 Undang-undang Nomor 1 Tahun 2009 memberikan batasan pengertian mengenai Badan Usaha Bandar Udara adalah badan usaha milik Negara, badan usaha milik Negara, atau badan hokum Indonesia berbentuk perseroan Terbatas atau koperasi. Permasalahannya apakah BP Batam berbentuk salah satu badan yang telah dibatasi pengertainnya dalam Pasal 1 angka 43 tersebut. Dengan demikian bisa dikatakan PP Nomor 65/2014 tidak selaras dengan ketentuan Undang-undang Nomor 1 tahun 2009 tentang Penerbangan.

\section{Perbandingan Kondisi Pembangunan Kota Batam Sebelum dan Sesudah Penerapan Otonomi Daerah}

Selama berlangsungnya penyelenggaraan otonomi daerah, terdapat dua sisi implikasi dari implementasi otonomi daerah selama ini, yakni keberhasilan-keberhasilan dan sekaligus problem-problem yang dihadapi. Pembangunan Kota Batam tidak bisa dilihat dari satu sisi Otonomi Daerah saja, sebab jauh sebelum Otda diterapkan di kota ini, Badan Pengusahaan Kawasan Batam (dulu Otorita Batam) telah lebih dulu hadir dan menjadi pionir pembangunan pulau ini hingga menjadi sebuah destinasi investasi asing di Indonesia. Tentu kita bisa melihat bagaimana tren pertumbuhan dan pembangunan ekonomi kota ini pada masa sebelum dan sesudah diimplementasikannya Otonomi Daerah yaitu ketika Pemkot Batam hadir menjadi pelaksana desentralisasi pemerintahan di daerah.

a. Pertumbuhan Ekonomi

\section{Pertumbuhan Ekonomi di Batam Sebelum Pelaksanaan Otonomi Daerah}

Menurut kajian ISEI Batam (2012) masa keemasan Batam bisa dikatakan terjadi pada era 1990 - 1997, di mana pada saat itu arus masuk investasi asing, tenaga kerja, dan pertumbuhan ekonomi melesat sangat tinggi. Walaupun trennya menunjukkan penurunan, namun secara nilai masih lebih tinggi dibandingkan provinsi induk saat itu yakni Riau dan juga Indonesia. 
Data BPS Batam menyebutkan selama periode 1995-1997 ekonomi Batam melesat dengan angka pertumbuhan berturut turut 17,41\%, $18,09 \%$, dan $13,55 \%$, jauh di atas pertumbuhan daerah lainnya di Propinsi Riau yang hanya berada pada kisaran angka dibawah 10\%, maupun pertumbuhan rata-rata ekonomi Riau serta pertumbuhan rata-rata ekonomi nasional pada periode yang sama. Sementara pada 1998, pada saat sebagian besar daerah tingkat II di Riau mengalami laju pertumbuhan negatif, Batam masih mampu tumbuh sebesar 3,08\%, jauh diatas pertumbuhan ekonomi nonmigas Riau yang merosot tajam menjadi negatif $1,93 \%$ dan pertumbuhan ekonomi nasional yang negatif 14,78\%. Pada 1999, sementara ekonomi Indonesia hanya mampu tumbuh $0,35 \%$ ekonomi Batam terus melesat ke angka 5,49\%.

Gambar 1. Pertumbuhan Ekonomi Batam $1991-1999$

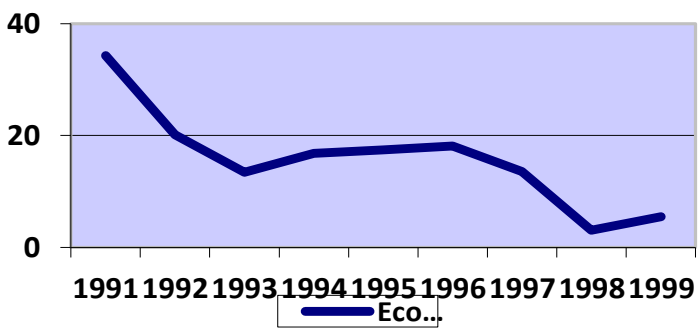

\section{Pertumbuhan Ekonomi di Batam Setelah Pelaksanaan Otonomi Daerah}

Sejak itu, laju pertumbuhan ekonomi Batam tidak pernah lagi mencapai level $10 \%$ hingga memasuki tahun 2000 hingga 2011 lalu. Bahkan, ketika Otonomi Daerah diberlakukan dengan hadirnya Pemkot Batam, ekonomi Batam seolah terhenti pada level 7-8\%.

Gambar 2. Pertumbuhan Ekonomi Batam $2000-2011$

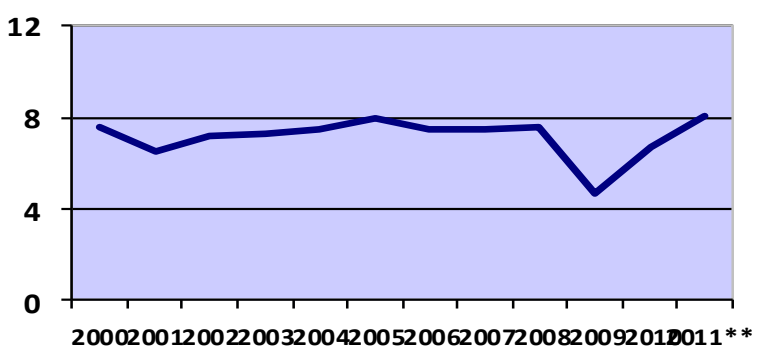

Sumber: BPS Kota Batam
Pada Gambar di atas menunjukkan tren pertumbuhan ekonomi Batam selama periode 2000 - 2011 masih meningkat kendati sempat anjlok pada 2009 menjadi 4,6\% akibat tekanan krisis global yang memaksa industri manufaktur di Batam mengurangi lini produksi.

\section{b. Investasi}

\section{Pertumbuhan Investasi di Batam Sebelum Pelaksanaan Otonomi Daerah}

Arus masuk investasi baik investasi pemerintah, domestik dan asing ke Pulau Batam selama era 1990 - 1999 juga menunjukkan tren yang meningkat dari sisi jumlah proyek dan nilai investasinya.

Grafik 3. Investasi Swasta (Asing + Domestik) di Pulau Batam Periode 1990 1999

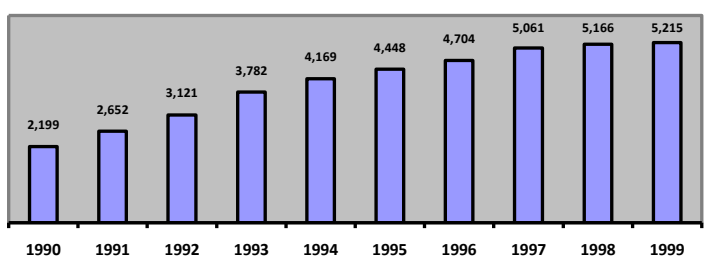

Sumber: Batam Development Update June 1999, diterbitkan oleh Otorita Batam tahun 1999.

Pertumbuhan investasi di Pulau Batam menunjukkan angka yang tinggi, yaitu sebesar 184\% dari tahun 1990 sampai dengan tahun 1999. Pada tahun 1990 modal investasi yang ditanamkan oleh pemerintah adalah sebesar US\$573 juta dan naik di tahun 1999 menjadi US\$1,626 miliar. Investasi pemerintah tersebut mampu memicu investasi swasta untuk masuk ke Batam US\$2,199 miliar pada 1990 meningkat menjadi US\$5,215 miliar pada 1999. Dilihat dari jenis investasi yang masuk ke Batam selama periode tersebut, sebanyak $50,83 \%$ bergerak di sektor industri meliputi manufaktur perakitan elektronik, perkapalan, dan off-shore, kemudian 20,26\% bergerak di sektor perdagangan dan jasa, sebanyak $15,16 \%$ bergerak di sektor properti dan real estate, dan $12,82 \%$ bergerak di sektor pariwisata.

Tingginya investasi swasta asing dan domestik yang masuk ke Pulau Batam selama periode tersebut, telah memicu arus urbanisasi pekerja yang berasal dari berbagai wilayah di Indonesia menuju ke Batam. Pada masa itu, 
Muhammad, Wahyudi, Samsubar, \& Agus, Dualisme Kelembagaan antara Pemerintah...

kebutuhan akan tenaga kerja sangat tinggi karena permintaan di sektor industri manufaktur yang didominasi oleh perakitan elektronik dan perkapalan.

\section{Pertumbuhan Investasi di Batam Setelah Pelaksanaan Otonomi Daerah}

Memasuki era Otonomi Daerah pada 1999 dan mulai diresmikannya Pemkot Batam pada tahun 2000 sampai dengan tahun 2010, total investasi yang masuk di Batam mencapai US\$14,41 miliar yang terdiri dari investasi pemerintah sebesar US $\$ 2,7$ miliar dan investasi swasta (asing dan domestik) sebesar US $\$ 11,64$ miliar dengan total perusahaan asing yang beroperasi di daerah ini sebanyak 1.247 perusahaan. Dari data terlihat bahwa Selama periode 2000 - 2010, investasi swasta di Batam tumbuh hampir 90\%, namun menurun dibandingkan pada periode sebelum pelaksanaan otonomi daerah 1990 - 1999 yang tumbuh $184 \%$.

Grafik 4. Investasi Swasta (Asing + Domestik) di Pulau Batam Periode 2000 2010

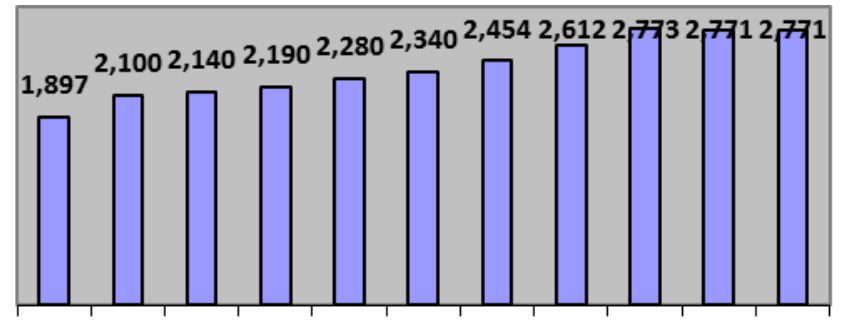

20002001200220032004200520062007200820092010 lain, kawasan ekonomi khusus Shenzhen di China yang menyumbang 75 persen dari pendapatan wilayah Shenzen sebesar US\$114,5 miliar dan memiliki pendapatan per kapita US\$13.200.

Adapun secara internal, penurunan daya saing disebabkan beberapa hal, mulai dari dualisme pengelolaan wilayah antara Pemkot dan BP Batam, dualisme tanggungjawab vertikal BP Batam ke Dewan Kawasan dan Menteri Keuangan, ledakan penduduk, sampai dengan maraknya penyelundupan. Dualisme pengelolaan wilayah ini menyebabkan Batam tidak kompetitif karena perizinan menjadi lamban, tumpang tindih pengelolaan tanah, ketidakpastian hukum bagi investor, hingga penyediaan infrastruktur yang belum memenuhi standar internasional.

Penurunan daya saing internal tersebut memberikan dampak yaitu sebanyak 30 persen dari ratusan perusahaan di Batam berencana memindahkan pabriknya ke negara lain. Negara tujuan kepindahan perusahaan tersebut antara lain Malaysia dan Vietnam karena kedua negara tersebut memberikan dukungan investasi yang lebih baik dan kondusif. Hal yang tidak mungkin dihindari dari dampak tersebut adalah banyak pekerja yang akan mengalami Pemutusan Hubungan Kerja (PHK). Terdapat kurang lebih 2.000 orang karyawan yang akan kehilangan pekerjaan. Ini akan menambah jumlah pengangguran di Batam. Padahal, saat ini pencari kerja di Batam selalu bertambah

\section{SIMPULAN DAN SARAN}

\section{Kesimpulan}

Berdasarkan hasil analisis dan pembahasan yang telah dikemukakan dalam bab terdahulu serta dikaitkan dengan tujuan penelitian ini, maka dapat dikemukakan beberapa kesimpulan berikut ini :

a. Hasil penelitian menunjukan fakta bahwa permasalahan utama dalam pengelolaan pemerintahan di Kota Batam adalah terjadinya dualisme kewenangan antara Pemerintah Kota dan Badan Pengusahaan Batam. Lahirnya Kota Batam menimbulkan tumpang tindih kewenangan antara Pemerintah Kota Batam dengan Badan Pengusahaan atau Otorita Batam. Eksistensi kedua lembaga yang didukung oleh struktur 
dan substansi hukum yang berbeda menyebabkan kebijakan pengelolaan Pulau Batam tidak harmonis. Keberadaan Badan Pengusahaan yang didahului oleh Otorita Batam berdasarkan Keputusan Presiden Nomor 41 Tahun 1973 dan memiliki kewenangan untuk melakukan pengelolaan Pulau Batam dan semakin diperkuat dengan lahirnya Undang-Undang Nomor 36 Tahun 2000 sebagaimana telah diubah dengan Keputusan Presiden Nomor 44 Tahun 2007, serta Peraturan Pemerintah Nomor 46 Tahun 2007 sebagaimana telah diubah dengan Peraturan Pemerintah Nomorr 5 Tahun 2011 secara vis a vis dengan Undang-Undang Nomor 22 Tahun 1999 sebagaimana telah diubah dengan Undang- Undang Nomor 32 Tahun 2004 serta Undang- Undang Nomor 53 Tahun 1999.

b. Hasil penelitian menunjukkan fakta bahwa terjadi tumpang tindih kewenangan antara Pemerintah Kota dan Badan Pengusahaan Batam terjadi dalam beberapa sektor antara lain dalam hal: hak pengelolaan lahan atau tanah di Batam, tumpang tindih dalam hal perizinan di Batam, benturan kewenangan pengelolaan kepelabuhanan, benturan kewenangan pengelolaan kebandarudaraan, dan benturan kewenangan pengelolaan fungsi kawasan pariwisata.

c. Hasil penelitian membuktikan bahwa permasalahan yang muncul setelah penerapan otonomi daerah di Batam, antara lain : terajadinya perlambatan ekonomi Batam terutama terlihat bahwa pertumbuhan ekonomi dan investasi menurun drastis, munculnya beberapa masalah sosial di Batam, lemahnya sinergi antar institusi, ketidakpastian hukum, serat merosotnya daya saing ekonomi Batam.

\section{Saran}

Setelah memperhatikan berbagai persoalan faktual yang terjadi di lapangan dan prospek Batam pada masa mendatang, maka penelitian ini menawarkan beberapa rekomendasi yang bisa dipertimbangkan untuk diimplementasikan dalam mengatasi berbagai hambatan yang terjadi di lapangan. Dalam rekomendasi jangka pendek, diusulkan adanya kelanjutan pembahasan Rancangan Peraturan Pemerintah tentang Hubungan Kerja Pemkot Batam dan Badan Pengusahaan Batam, perlu adanya peningkatan Sinergi dalam Pembangunan Ekonomi khususnya hubungan antara Pemerintah Kota dan Badan Pengusahaan Batam. Sedangkan rekomendasi Jangka Panjang dalam rangka penyelesaian permasalahan jangka Panjang, dalam penelitian ini mengusulkan untuk membentuk sebuah pemerintahan khusus/ otonomi khusus melalui Undang - Undang Khusus Batam. Namun, urgensi terhadap dibentuknya sebuah pemerintahan khusus/otonomi khusus di Pulau Batam sebaiknya dikaji lebih mendalam melalui penelitian berikutnya.

\section{DAFTAR PUSTAKA}

[1] Audrey G., Konflik dalam Pengelolaan Kota Batam, Jakarta : Tesis Magister Sains Perkotaan Universitas Indonesia, 2007.

[2] BPMPD Pemerintah Provinsi Kepri, Quo Vadis, Kawasan Ekonomi Khusus (KEK). Tanjung Pinang : Penerbit RajaGrafindo Persada, 2010.

[3] BP Batam, Laporan BP Batam, Badan Pengusahaan Batam, 2011

[4] Cohen, J.M. \& Peterson, S. B., Administrative Decentralization : Strategies for Developing Countries Connecticut: Kumahan Press, 1999.

[5] Creswell, John W \& Vicki L. Plano Clark. Designing and Conducting: Mixed Methods Research. London: Sage Publications, 2007.

[6] Hoessein, B., "Pergeseran paradigma otonomi daerah dalam rangka reformasi administrasi publik di Indonesia". Makalah dalam Seminar Reformasi Hubungan Pusat-Daerah Menuju Indonesia Baru : Beberapa Masukan Kritis untuk Pembahasan, 1999.

[7] Heri Muliono, Merajut Batam Masa Depan, Menyongsong Status Free-Trade Zone, Jakarta : Penerbit LP3ES, 2011.

[8] Hidayat, Syarif, Desentralisasi dan Otonomi Daerah dalam Perspektif State-Society Relation, Jurnal Politik Vol. 1 No. 12008 Undang-Undang Otonomi Daerah dan 
Muhammad, Wahyudi, Samsubar, \& Agus, Dualisme Kelembagaan antara Pemerintah...

Proses Transisi Implementasinya yang diselenggarakan ASPRODIA-UI. Jakarta: 27 Maret, 2008.

[9] Investment Opportunities and Prospect in the Batam Free Trade Zone, Indonesia, Batam Indonesia Free Zone Authority, 2010

Iskandar Development Region (IDR) Annual Report 2011

[10] Krismiyati Tasrin dkk, Kajian Pengembangan Desentralisasi Asimetris di Indonesia, Pusat Kajian dan Pendidikan dan pelatihan Aparatur I, Lembaga Administrasi Negara, Bandung, 2012

[11] Muhammad Sapta Murti , The Importance of Special Autonomy of Batam According to Implementation of ASEAN Economic Community 2015. Jurnal Rechts Vinding Volume 3 Nomor 2 Agustus 2015.

[12] Panjaitan, Rudi TH, Analisis Alternatif Kebijakan Pengelolaan Kawasan Berikat Batam dalam Mewujudkan Batam sebagai Obyek Pertumbuhan Segitiga Emas, Yogyakarta : Tesis MAP UGM, 2003.

[13] Putra, Bayu , Dampak Dualisme Kewenangan dalam Pelayanan Administrasi Penananaman Modal : Studi Kasus Implementasi Desentralisasi di Kota Batam, Yogyakarta : Tesis MAP UGM, 2014

[14] Rondinelli, Dennis A., John R. Nellis \& G. Shabbir Cheema, Decentralization in Developing Countries: A Review of Recent Experience, Washington, D.C: The World Bank, 1983

[15] Suwandi, Made. Pokok-Pokok Pikiran Konsepsi Otonomi Daerah Indonesia dalam Upaya Mewujudkan Pemerintah Daerah yang Demokratis dan Efesien. Jakarta: tidak diterbitkan, 2002

[16] Tim Small Research Ikatan Sarjana Ekonomi Indonesia (ISEI) Cabang Batam, Kajian Hubungan Kerja Pemerintah Kota Batam dan Badan Pengusahaan Kawasan FTZ terhadap Percepatan Pembangunan Ekonomi dan Investasi dalam Era Otonomi Daerah di Kota Batam, Agustus 2012.
[17] UU No. 32/2004 jo. UU No. 22/1999 tentang Pemerintahan Daerah

[18] UU No. 53/1999 tentang Pembentukan Kota Batam

[19] UU No 44 Tahun 2007 jo. Perppu No. 1 12007 jo. UU No. 36/2000 jo. Perppu No. $1 / 2000$ tentang Kawasan Perdagangan Bebas dan Pelabuhan Bebas

[20] PP No. 46 tahun 2007 tentang Kawasan Perdagangan Bebas dan Pelabuhan Bebas Batam. 